\title{
THE BIOLOGICAL ACTIVITY OF ALTERNARIA SPECIES
}

\section{K.S. Tsyganenko, Ya.I. Savchuk, L.T. Nakonechna, I.M. Kurchenko}

\author{
Zabolotny Institute of Microbiology and Virology, NAS of Ukraine, \\ 154 Akad. Zabolotny Str., Kyiv, 03143, Ukraine \\ e-mail:tsyga@ukr.net
}

\begin{abstract}
Alternaria species isolated from different econiches produce a wide variety of biologically active metabolites. The aim of this article was the evaluation of the biological activity spectrum of the small-spored Alternaria species from different trophic groups (saprophytes, endophytes and plant pathogens) using screening of biologically active metabolites on a wide set of test organisms, and selection of promising strainsproducers. Methods. Antibiotic, antifungal and phytotoxic activities of culture filtrates and chloroform extracts were determined by agar diffusion assay method. Results. 19\% of cultural filtrates among of 64 studied strains showed the biological activity at least against one test organism. The most of these fungi belong to endophytic strains and were active against test plant pathogenic fungi, bacteria and algae. Chloroform extracts of cultural filtrates of 33\% of fungi showed biological activity against at least to one test organism. The obtained extracts had specific activity mainly against certain test culture. These preparations selectively inhibited the growth of Staphylococcus aureus B-909, Chlorella vulgaris 191 and Rizoctonia solani 16036. Conclusions. The screening of 64 strains of the Alternaria fungi isolated from different ecological niches allows concluding that they have low biological activity. Endophytic Alternaria strains were characterized by wider spectrum of activities than plant pathogenic and soil ones. They inhibited all test organisms except Gram negative bacteria and yeast-like fungi. The biologically active metabolites of endophytic Alternaria strains including high-molecular compounds play important role in mutual coexistence endophytic fungi and host-plants as well as their spread. Chloroform extracts of the soil saprophytes had comparably high activity especially against fungi and algae. Obviously these low-molecular compounds facilitate to adaptive survival of saprophytic fungi in soil habitats with high biodiversity. For further studies were selected two strains: highly phytotoxic A. brassicicola 2855 and A. longipes 16800 (an antagonist of $S$. aureus B-909).
\end{abstract}

Keywords: Alternaria, endophytes, plant pathogens, saprophytes, biologically active metabolites.

Alternaria is widely spread in the environment fungal genus that can be isolated from different habitats. Alternarioid hyphomycetes include saprophytic, endophytic and pathogenic species, the most of them are considered to be cosmopolitan saprobes [1]. The strains of this genus can infect a large number of economically important plants [2], and at the same time can be potent airborne allergens determined as an causative agent of childhood asthma and infection of upper respiratory tract in humans $[3,4]$.

The Alternaria genus was first described in 1817 by Nees with $A$. tenuis as the type, and its taxonomy is still under discussion. Today, according to conidia size, a main segregation consists of the two groups, such as the large-spored (conidia are 60-100 $\mu$ ) and small-spored (conidia are $<60 \mu$ ). [5]. The small- 
spored species are cosmopolitan saprotrophs, plant pathogens, allergens, and mycotoxin producers, being the most common food contaminants [6].

Altenaria species, as plant pathogens, are well known for their ability to produce a wide spectrum of secondary metabolites [7]. These metabolites include various plant pathogenesis related toxins, both host and non-host specific. Some metabolites are unique to one Alternaria species, but most metabolites are produced by more than one species. In general, there are about 270 isolated and described substances [8-13].

Alternaria metabolites exhibit a variety of biologically activities such as phytotoxic and antimicrobial properties, which have drawn the attention of many chemists, pharmacologists, and plant pathologists in research programs as well as in applied studies [14]. The metabolites from these fungi can be divided into several categories that include nitrogen-containing compounds, steroids, terpenoids, pyranones, quinones, phenols, etc. [15]; or they can be divided into three different structural groups: the dibenzopyrone derivatives alternariol, alternariol monomethyl ether, and altenuene; the perylene derivatives - altertoxins I, II and III; and the tetramic acid derivatives tenuazonic acid, etc. Most of them are the ones that can be found as main contaminants of foodstuffs [6].

The main research direction of our laboratory is the study of new biologically active substances from different fungi. Previously, according to the screening results, we carried out a comparative evaluation of the ability of Aspergillus, Gliocladium, Ulocladium, Myrothecium and other genera to produce biologically active metabolites $[16,17]$. The main aim of present study was the evaluation of the biological activity spectrum of the small-spored Alternaria fungi isolated from different habitats (saprophytic, endophytic and plant pathogenic species) using screening of biologically active metabolites on a wide set of test organisms, and selection of promising strains-producers.

Materials and methods. We used 64 strains of Alternaria genus from the Culture collection of Department of Physiology and Taxonomy of Micromycetes of Zabolotny Institute of Microbiology and Virology of the NAS of Ukraine. The 26 of them were soil saprophytes, 17 - endophytes, and 21 - plant pathogens. We studied small-spored Alternaria species belonging to A. tenuissima (17 strains), A. alternata (26 strains), A. longipes (7 strains), A. infectoria (2 strains), A. brassicicola (1 strain) and 10 strains of Alternaria sp. Species were identified by their cultural and morphological features [18].

For screening we used cultural filtrates of Alternaria strains from different habitats and their chloroform extracts. Fungi were grown in modified CzapekDox medium containing (g/l): glucose - 20.0; $\mathrm{NaNO}_{3}-1.0 ; \mathrm{KH}_{2} \mathrm{PO}_{4}-1.0$; $\mathrm{KCl}-0.5 ; \mathrm{MgSO}_{4} \times 7 \mathrm{H}_{2} \mathrm{O}-0.5 ; \mathrm{FeSO}_{4} \times 7 \mathrm{H}_{2} \mathrm{O}-0.01$ in distilled water; $\mathrm{pH} 5.2$ [19].

Static fermentation was carried out in $500 \mathrm{ml}$ Erlenmeyer flasks with $100 \mathrm{ml}$ of working volume at $26^{\circ} \mathrm{C}$ for 14 days. The flasks were inoculated by suspension containing $1 \times 10^{6}$ conidia/ml ( 0.1 part of working volume). After fermentation the biomass was filtered and cultural filtrates were used for obtaining of extracts by three-time chloroform extraction following by evaporation to a minimum volume under reduced pressure on a rotary evaporator. 
A wide set of test cultures was used to determine the biological activities of the cultural filtrates and the chloroform extracts: Gram positive bacteria (Bacillus subtilis B-902, Staphylococcus aureus B-909, Micrococcus varians Ac-613), Gram negative bacteria (Pseudomonas aeruginosa B-900, Escherichia coli B-916, Salmonella enterica B-921), and plant pathogenic bacteria (Pectobacterium carotovorum 8636, Agrobacterium tumefaciens 8464, A. tumefaciens 8628, P. syringae pv. syringae 8523) - for antibiotic activity; yeasts-like fungi (Candida albicans 690, Kluyveromyces marxianus 899, Trichosporon cutaneum 1502), and plant pathogenic fungi (Phoma betae 16865, Rizoctonia solani 16036, Fusarium culmorum 50716, F. lactis 50678)for antifungal activity; green algae (Chlorella vulgaris 190, C. vulgaris 191, C. kessleri 200, C. kessleri 205) - for phytotoxic activity.

Test bacteria were grown on meat peptone agar, test fungi - on malt extract agar, test algae - on mineral media containing (g/l): $\mathrm{NaNO}_{3}-1.0 ; \mathrm{K}_{2} \mathrm{HPO}_{4}-$ $0.25 ; \mathrm{MgSO}_{4}-0.513 ; \mathrm{NH}_{4} \mathrm{Cl}-0.05 ; \mathrm{CaCl}_{2}-0.058 ; \mathrm{FeCl}_{3}-0.003$; agar - 15.0 in distilled water, $\mathrm{pH} 7.0$.

The screening was carried out by agar well and disc diffusion assay methods $[20,21]$. $0.2 \mathrm{ml}$ of each cultural filtrate was added per well. Paper discs were dipped in chloroform extracts. Each disc obtained $10.0 \mu$ of certain chloroform extract and then dried from chloroform in a stream of air. Diameters of growth inhibition zones of test cultures were measured after 24 hours for bacteria and after 48-72 hours - for fungi and algae. All experiments were performed in triplicate.

Results. The table contains data only for strains that inhibited the growth of at least one of the test organisms. The table presents results for only $19 \%$ of the studied strains, cultural filtrates of which showed the biological activity.

Only two strains had activity against various group of test organisms. Alternaria infectoria 16837 acted on all four strains of test algae and on three strains of plant pathogenic fungi; and A. longipes 16800 influenced on S. aureus B-909 and two C. kessleri strains. Both of these strains belong to the endophytic group. Endophytic A. alternata 16828 showed antibiotic activity against $S$. aureus B-909 and belonging to the same group $A$. infectoria $16838-$ against all four strains of plant pathogenic bacteria. Plant pathogen $A$. alternata 16762 showed antibiotic activity against Gram positive test bacteria. Cultural filtrates of endophytic A. alternata 16798 and soil saprophytic A. brassicicola 2855 had phytotoxic activity against two strains of $C$. kessleri and all four strains of test algae, respectively.

The $33 \%$ of chloroform extracts of the studied strains were characterized by the biological activity. Notably, the most of the studied extracts showed selective activity exclusively against one of the test organisms. In particular, endophytic A. longipes 16801, A. tenuissima 16821, A. alternata 16762 and plant pathogenic Alternaria sp. 8 demonstrated antibiotic activity exclusively against $S$. aureus B-909. Soil saprophytes A. tenuissima 1236 and Alternaria sp. 2449 inhibited exclusively growth of $R$. solani 16036 ; A. alternata 33 from this group had antifungal activity only against $F$. culmorum 50716 . Soil saprophytes A. alternata 1906, Alternaria sp. 53, endophyte A. tenuissima 16816, and plant pathogens $A$. tenuissima 3 and $A$. alternata 5 showed phytotoxic activity exclusively against one of test algae. 
Table

The biological activities of Alternaria fungi

\begin{tabular}{|c|c|c|c|c|c|c|c|c|c|c|c|c|c|c|c|c|c|c|c|c|c|c|}
\hline \multirow{3}{*}{ 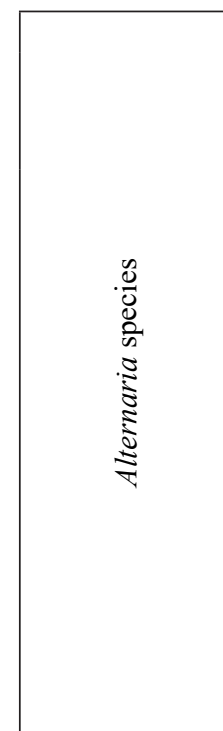 } & \multirow[b]{3}{*}{ 墕 } & \multicolumn{21}{|c|}{ Diameter of the growth inhibition zone of test organisms, $\mathrm{mm}$} \\
\hline & & \multicolumn{3}{|c|}{$\begin{array}{c}\text { Gram } \\
\text { negative } \\
\text { bacteria }\end{array}$} & \multicolumn{3}{|c|}{$\begin{array}{c}\text { Gram } \\
\text { positive } \\
\text { bacteria }\end{array}$} & \multicolumn{4}{|c|}{$\begin{array}{c}\text { Plant } \\
\text { pathogenic } \\
\text { bacteria }\end{array}$} & \multicolumn{4}{|c|}{ Green algae } & \multicolumn{3}{|c|}{$\begin{array}{c}\text { Yeasts- } \\
\text { like fungi }\end{array}$} & \multicolumn{4}{|c|}{\begin{tabular}{|c|} 
Plant \\
pathogenic \\
fungi
\end{tabular}} \\
\hline & & $\mid$ & 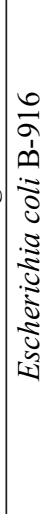 & 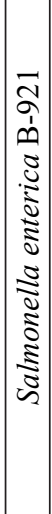 & 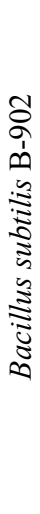 & 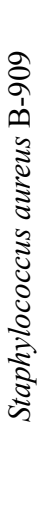 & 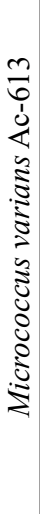 & 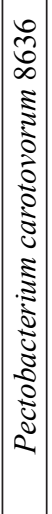 & 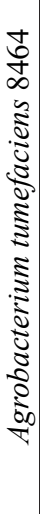 & 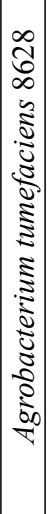 & 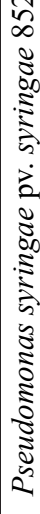 & 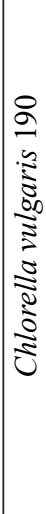 & 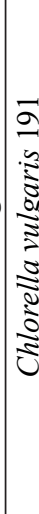 & 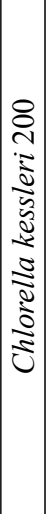 & 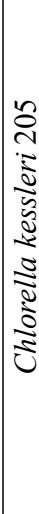 & & 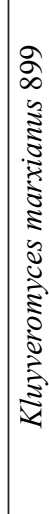 & 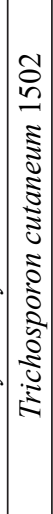 & 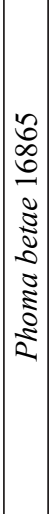 & 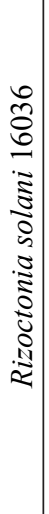 & & 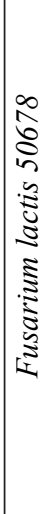 \\
\hline \multicolumn{23}{|c|}{ Cultural filtrates } \\
\hline \multicolumn{23}{|l|}{ Soil saprophytes } \\
\hline A. brassicicola & 2855 & 0 & 0 & 0 & 0 & 0 & 0 & 0 & 0 & 0 & 0 & 27 & 30 & 33 & 38 & 0 & 0 & 0 & 0 & 0 & 0 & 0 \\
\hline Alternaria & & 0 & 0 & 0 & 0 & 0 & 0 & 0 & 0 & 0 & 0 & 0 & & 0 & & & & 0 & 28 & 0 & 20 & 0 \\
\hline \multicolumn{23}{|l|}{ Endophytes } \\
\hline A. alternata & 5798 & 0 & 0 & 0 & 0 & 0 & 0 & 0 & 0 & 0 & 0 & 0 & 0 & 18 & 20 & 0 & 0 & 0 & 0 & 0 & \begin{tabular}{|l|}
0 \\
\end{tabular} & 0 \\
\hline A. alternata & 2 & 0 & 0 & 0 & 0 & 0 & 0 & 0 & 0 & 0 & 0 & 0 & 0 & 0 & 0 & & 0 & 0 & 30 & 36 & 25 & 0 \\
\hline al & 1 & 0 & 0 & 0 & 0 & 15 & 0 & 0 & 0 & 0 & 0 & 0 & 0 & 0 & 0 & & 0 & 0 & 0 & 0 & 0 & 0 \\
\hline 1. in & 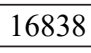 & 0 & 0 & 0 & 0 & 0 & 0 & 18 & 20 & 29 & 26 & 0 & 0 & 0 & 0 & U & 0 & 0 & 0 & 0 & \begin{tabular}{|l|l|}
0 \\
\end{tabular} & 0 \\
\hline A. infectoria & 7 & 0 & 0 & 0 & 0 & 0 & 0 & 0 & 0 & \begin{tabular}{|l|l|}
0 \\
\end{tabular} & 0 & 50 & 52 & 30 & 30 & 0 & 0 & 0 & 24 & 34 & 24 & 0 \\
\hline A. longipes & & 0 & 0 & 0 & 0 & 25 & 0 & 0 & 0 & 0 & 0 & 0 & 0 & 23 & 28 & & 0 & 0 & 0 & 0 & \begin{tabular}{|l|l}
0 & \\
\end{tabular} & 0 \\
\hline \multicolumn{23}{|l|}{ Plant pathogens } \\
\hline A. alternata & 818 & 0 & 0 & 0 & 0 & 0 & 0 & \begin{tabular}{|l|}
0 \\
\end{tabular} & 0 & 0 & 0 & 0 & 0 & 0 & 0 & U & 0 & 0 & 0 & 23 & \begin{tabular}{|l|}
0 \\
\end{tabular} & 0 \\
\hline A. alternata & 2 & 0 & 0 & 0 & 12 & 22 & 0 & 0 & 0 & 0 & 0 & 0 & 0 & 0 & 0 & 0 & 0 & 0 & 0 & 0 & 0 & 0 \\
\hline A. all & 3 & 0 & 0 & 0 & 0 & ( & 0 & 0 & 0 & 0 & 0 & 0 & 0 & 0 & 0 & & 0 & 0 & 0 & 0 & 26 & 0 \\
\hline 4. al & 8 & 10 & 0 & 0 & 0 & 0 & 0 & 0 & 0 & 0 & 0 & 0 & 0 & 0 & 0 & 0 & 0 & 0 & 29 & 20 & \begin{tabular}{|l|l}
0 & \\
\end{tabular} & 0 \\
\hline \multicolumn{23}{|c|}{ Chloroform extracts } \\
\hline \multicolumn{23}{|l|}{ Soil saprophytes } \\
\hline A. tenuissima & 803 & 11 & 0 & 0 & 16 & 0 & 0 & 21 & 18 & 0 & 0 & 0 & 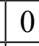 & 0 & 0 & & 0 & 0 & 0 & 0 & \begin{tabular}{|l|l|}
0 \\
\end{tabular} & 0 \\
\hline 4. te & 20 & 0 & 0 & 0 & 0 & 0 & 0 & 0 & 0 & 0 & 0 & 22 & 0 & 0 & 0 & & 0 & 0 & 0 & 18 & 32 & 0 \\
\hline ssima & 1236 & 0 & 0 & 0 & 0 & 0 & 0 & 0 & 0 & 0 & 0 & 0 & 0 & 0 & 0 & 0 & 0 & 0 & 0 & 21 & 0 & 0 \\
\hline A. alternata & 1916 & 0 & 0 & 0 & 0 & 0 & 0 & 0 & 0 & 0 & 0 & 0 & 26 & 0 & 0 & 0 & 0 & 0 & 0 & 0 & 0 & 0 \\
\hline A. alternata & 3 & 0 & 0 & 0 & 0 & 0 & 0 & 0 & 0 & 0 & 0 & 0 & 0 & 0 & 0 & 0 & 0 & 0 & 0 & 0 & 50 & 0 \\
\hline A. brassicicola & 2855 & 0 & 0 & 0 & 0 & 0 & 0 & 0 & 0 & 0 & 0 & 0 & 0 & 0 & 0 & 0 & 0 & 0 & 24 & 20 & 24 & 0 \\
\hline Alternaria sp. & 53 & 0 & 0 & 0 & 0 & 0 & 0 & 0 & 0 & 0 & 0 & 0 & 0 & 18 & 0 & 0 & 0 & 0 & 0 & 0 & 0 & 0 \\
\hline \begin{tabular}{|l} 
Alternaria sp. \\
\end{tabular} & 2449 & 0 & 0 & 0 & 0 & 0 & 0 & 0 & 0 & 0 & 0 & 0 & 0 & 0 & 0 & 0 & 0 & 0 & 0 & 20 & 0 & 0 \\
\hline Alternaria $\mathrm{sp}$ & 1584 & 0 & 0 & 0 & 0 & 0 & 0 & 12 & 0 & 0 & 0 & 0 & 0 & 0 & 0 & 0 & 14 & 0 & 0 & 20 & 0 & 0 \\
\hline Alternaria sp. & & 0 & 0 & 0 & 0 & 0 & 0 & \begin{tabular}{|l|}
0 \\
\end{tabular} & 0 & 0 & 0 & 0 & 0 & 0 & 0 & 0 & 0 & 0 & 20 & 16 & \begin{tabular}{|l|}
0 \\
\end{tabular} & 0 \\
\hline \multicolumn{23}{|l|}{ Endophytes } \\
\hline A. tenuissima & 816 & 0 & 0 & 0 & 0 & 0 & 0 & \begin{tabular}{|l|}
0 \\
\end{tabular} & 0 & 0 & 0 & 0 & 7 & 0 & 0 & 0 & 0 & 0 & 0 & 0 & 0 & 0 \\
\hline A. longip & 6799 & 0 & 0 & 0 & 0 & 0 & 0 & 0 & 0 & 0 & 0 & 0 & 7 & 0 & 0 & 0 & 10 & 0 & 0 & 0 & 0 & 0 \\
\hline 4. longit & 16801 & 0 & 0 & 0 & 0 & 17 & 0 & 0 & 0 & 0 & 0 & 0 & 0 & 0 & 0 & & 0 & 0 & 0 & 0 & 0 & 0 \\
\hline
\end{tabular}




\begin{tabular}{|c|c|c|c|c|c|c|c|c|c|c|c|c|c|c|c|c|c|c|c|c|c|c|}
\hline \multirow[b]{3}{*}{ 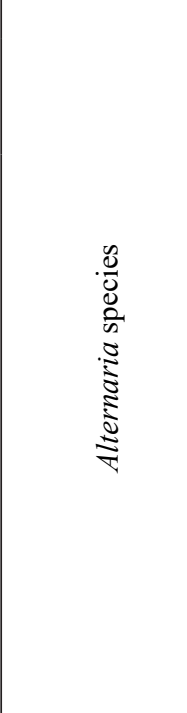 } & \multirow[b]{3}{*}{ 蕇 } & \multicolumn{21}{|c|}{ Diameter of the growth inhibition zone of test organisms, $\mathrm{mm}$} \\
\hline & & \multicolumn{3}{|c|}{$\begin{array}{c}\text { Gram } \\
\text { negative } \\
\text { bacteria }\end{array}$} & \multicolumn{3}{|c|}{\begin{tabular}{|c|} 
Gram \\
positive \\
bacteria
\end{tabular}} & \multicolumn{4}{|c|}{$\begin{array}{c}\text { Plant } \\
\text { pathogenic } \\
\text { bacteria }\end{array}$} & \multicolumn{4}{|c|}{ Green algae } & \multicolumn{3}{|c|}{\begin{tabular}{|c|} 
Yeasts- \\
like \\
fungi \\
\end{tabular}} & \multicolumn{4}{|c|}{$\begin{array}{c}\text { Plant } \\
\text { pathogenic } \\
\text { fungi }\end{array}$} \\
\hline & & 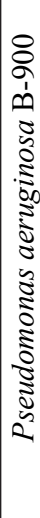 & 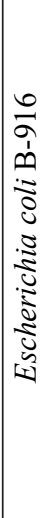 & 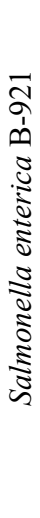 & $\begin{array}{l}1 \\
8 \\
\vdots \\
n \\
n \\
n\end{array}$ & 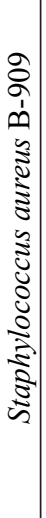 & 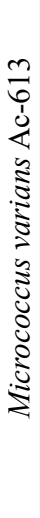 & $\begin{array}{r}0 \\
0 \\
0 \\
0 \\
\vdots \\
0 \\
0 \\
0 \\
0 \\
0 \\
0 \\
0 \\
\vdots \\
\vdots \\
0 \\
0 \\
0 \\
0 \\
0 \\
0 \\
0\end{array}$ & 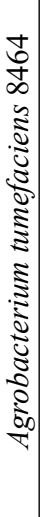 & $\frac{\tilde{a}}{3}$ & 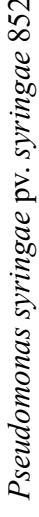 & 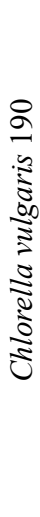 & 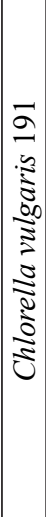 & 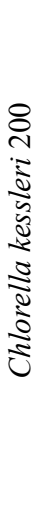 & 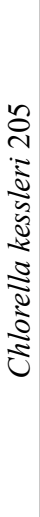 & 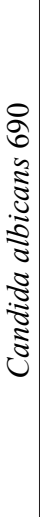 & 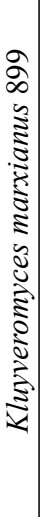 & 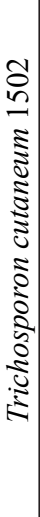 & 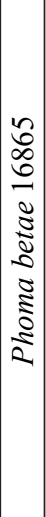 & 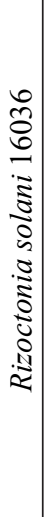 & 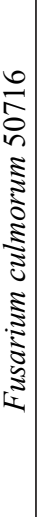 & $\overbrace{0}^{\infty}$ \\
\hline \multicolumn{23}{|l|}{ Plant pathogens } \\
\hline A. tenuissima & 6821 & 0 & 0 & 0 & 0 & 16 & 0 & 0 & 0 & 0 & 0 & 0 & 0 & 0 & 0 & 0 & 0 & 0 & 0 & 0 & 0 & 0 \\
\hline A. tenuissima & 16824 & 0 & 0 & 0 & 0 & 0 & 0 & 0 & 10 & 0 & 0 & 7 & 0 & 0 & 0 & 0 & 0 & 0 & 0 & 0 & 0 & 0 \\
\hline A. tenuissima & 3 & 0 & 0 & 0 & 0 & 0 & 0 & 0 & 0 & 0 & 0 & 0 & 7 & 0 & 0 & 0 & 0 & 0 & 0 & 0 & 0 & 0 \\
\hline A. alternata & 5 & 0 & 0 & 0 & 0 & 0 & 0 & 0 & 0 & 0 & 0 & 0 & 7 & 0 & 0 & 0 & 0 & 0 & 0 & 0 & 0 & 0 \\
\hline A. alternata & 6762 & 0 & 0 & 0 & 0 & 13 & 0 & 0 & 0 & 0 & 0 & 0 & 0 & 0 & 0 & 0 & 0 & 0 & 0 & 0 & 0 & 0 \\
\hline A. alternata & 18 & 0 & 0 & 0 & 0 & 0 & 0 & 0 & 0 & 0 & 0 & 0 & 8 & 0 & 0 & 0 & 0 & 0 & 0 & 23 & 0 & 0 \\
\hline A. longipes & 16820 & 0 & 0 & 0 & 0 & 10 & 0 & 0 & 13 & 0 & 0 & 7 & 7 & 0 & 10 & 0 & 0 & 0 & 0 & 0 & 0 & 0 \\
\hline Alternaria sp. & 8 & 0 & 0 & 0 & 0 & 15 & 0 & 0 & 0 & 0 & 0 & 0 & 0 & 0 & 0 & 0 & 0 & 0 & 0 & 0 & 0 & 0 \\
\hline
\end{tabular}

Note: The table shows the average value of three replicates; 0 - no activity; $\mathrm{p}<0.05$.

The chloroform extracts of soil saprophytes A. brassicicola 2855 and Alternaria sp. 397 had antifungal activity against plant pathogenic test fungi; A. tenuissima 1920 was characterized by antifungal and phytotoxic activities; Alternaria sp. 1584 inhibited the growth of plant pathogenic fungus $R$. solani 16036 , test bacterium $P$. carotovorum 8636 and yeast-like test fungus C. albicans 690 . Endophytic $A$. longipes 16799 had antifungal activity against one test alga C. vulgaris 191 and one yeast-like test fungus K. marxianus 899 .

The chloroform extract of plant pathogenic A. tenuissima 16824 showed antibiotic activity against $A$. tumefaciens 8464 and phytotoxic activity against C. vulgaris $190 ;$ A alternata 16818 had phytotoxic activity against C. vulgaris 191 and antifungal one against $R$. solani 16036; A. longipes 16820 showed phytotoxic and antibiotic (against $S$. aureus B-909 and A. tumefaciens 8464) activities.

The chloroform extract of soil saprophyte A. tenuissima 803 inhibited the growth of all bacterial strains from three test groups.

It should be noted, the test Gram negative bacteria E. coli B-916, S. enterica B-921, Gram positive M. varians Ac-613, yeast-like fungi C. albicans 690, T. cutaneum 1502, and plant pathogenic F. lactis 50678 were resistant to all cultural filtrates and chloroform extracts of the studied test strains. 
Discussion. The comparison of the biological activity of cultural filtrates and chloroform extracts of studied Alternaria strains has shown that only three of them had activity: soil saprophyte $A$. brassicicola 2855 and plant pathogens A. alternata 16818 and 16762 . The spectra of the action of the active metabolites did not always coincide. For example, cultural filtrate of A. brassicicola 2855 was characterized by high phytotoxic activity against test algae, while chloroform extract of this strain had activity against plant pathogenic fungi. This phenomenon could be explained by different metabolite profiles in the cultural filtrates and chloroform extracts of all studied fungi.

It was shown that the most of biologically active substances present in the cultural filtrates were not extracted with chloroform (Table). Consequently, these compounds by their nature can refer to peptides, enzymes, saccharides and other compounds that exhibit biological activity and are not extracted with chloroform by means of which are extracted usually low molecular weight antibiotics and toxins. It is known, that fungi of Alternaria genus synthesize the biologically active high-molecular compounds, such as lipase from A. brassicicola [22], polyketide synthase [23] and endopolygalacturonase from A. alternata [24].

On the other hand, small diameters of growth inhibition zones of the test organisms using chloroform extract discs indicated relatively low concentrations in the cultural filtrates of biologically active substances that did not inhibit growth of the test organisms. At the same time, the presence of selective action on a particular test organism gives the prospect for obtaining biologically active compounds with directional action. For example, in the case of the chloroform extract of $A$. alternata 33 that exclusively inhibited the growth of F. culmorum 50716.

In general, the screening of 64 strains of the Alternaria fungi isolated from different ecological niches allows concluding that they have low biological activity compared with previous screening of other genera [16, 17]. Each fungus is evolutionarily adapted to growth and spread on a substrate, to synthesis of necessary for its biologically active metabolites in certain ecological habitats. For the Alternaria fungi a main substrate is plants, in that they act both plant pathogenic and endophytic, and on the same time - soil. The cause of the low biological activity of Alternaria strains in our studies may be the synthetic nutrient medium composition, which does not include additional nutrient components that contribute to the natural habitats for the synthesis of biologically active substances necessary for the growth and spread of Alternaria fungi [25]. The main aim of this study was the evaluation of the biological activity spectrum of 64 strains of the Alternaria fungi from different habitats that includes the cultivation of fungi under standardized conditions and comparative analysis of their biological activities.

Studied cultural filtrates of the endophytic strains were characterized by wider spectrum of activities than plant pathogenic and soil ones. It had being inhibited all test organisms except Gram negative bacteria and yeast-like fungi. This phenomenon showed that endophytic Alternaria strains had the biologically active metabolites including high-molecular compounds that play important role in mutual coexistence endophytic fungi and host-plants as well 
as their spread $[26,27]$. It can be assumed that synthesized by endophytic fungi high molecular metabolites may belong to enzymes, peptides and/or their complexes with low molecular bioactive compounds.

Among of studied chloroform extracts the soil saprophytes had comparably high activities especially against test fungi and algae. Obviously these lowmolecular compounds facilitate to adaptive survival of saprophytic fungi in soil habitats with high biodiversity [28]. We can suppose that studied saprobes have a potential to biosynthesis of low-molecular metabolites of different chemical structure such as specific antibiotics, phyto- and mycotoxins.

According to the results of screening, A. brassicicola 2855 is the pathogen of Brassica species [29] and has phytotoxic activity; A. longipes 16800 is the pathogen of Nicotiana species and inhibits exclusively growth of $S$. aureus B-909; these strains were selected for further work [30]. A more detailed study of biologically active metabolites of these fungi has the prospect of creating preparations for both agricultural application and medicinal practice $[31,32]$.

\title{
БІОЛОГІЧНА АКТИВНІСТЬ РІЗНИХ ВИДІВ РОДУ ALTERNARIA
}

\author{
К.С. Циганенко, Я.І. Савчук, Л.Т. Наконечна, І.М. Курченко \\ Інститут мікробіології і вірусологї ім. Д.К. Заболотного НАН України, \\ вул. Академіка Заболотного, 154, Київ, 03143, Україна
}

Резюме

Види роду Alternaria, ізольовані з різних еконіш, синтезують широке коло біологічно активних метаболітів. Метою даної статті була оцінка спектру біологічної активності дрібноспорових видів роду Alternaria з різних трофічних груп (сапрофіти, ендофіти і фітопатогени) за результатами системного скринінгу біологічно активних метаболітів щодо широкого набору тест-організмів та відбір перспективних штамів-продуцентів. Методи. Антибіотичну, антифунгальну і фітотоксичну активність культуральних фільтратів і хлороформних екстрактів визначали методом дифузії в агар. Результати. 19\% культуральних фільтратів з 64 досліджених штамів проявляли біологічну активність щонайменше до одного з тест-організмів. Переважна більшість цих грибів належала до ендофітних штамів і була активною щодо фітопатогенних грибів, бактерій і водоростей. Хлороформні екстракти з культуральних фільтратів 33\% штамів проявляли біологічну активність принаймні щодо одного 3 тест-організмів. Отримані екстракти мали вибіркову специфічну дію щодо певної тест-культури. Ці препарати селективно інгібували ріст Staphylococcus aureus B-909, Chlorella vulgaris 191 і Rizoctonia solani 16036. Висновки. Скринінг 64 штамів грибів Alternaria, виділених з різних екологічних ніш, дозволив зробити висновок, що вони мають низьку біологічну активність. Ендофітні штами Alternaria характеризувалися ширшим спектром активностей, ніж фітопатогенні і грунтові. Вони інгібували усі тест-організми за винятком грамнегативних бактерій і дріжджоподібних грибів. Біологічно активні метаболіти ендофітних штамів Alternaria, включаючи високомолекулярні речовини, відіграють важливу роль у мутуалістичному співіснуванні ендофітних грибів і рослин-хазяїнів, а також у їхньому поширенні. Хлороформні екстракти грунтових сапрофітів мали порівняно високу активність особливо щодо 
грибів і водоростей. Очевидно, ці низькомолекулярні сполуки сприяють адаптивному виживанню сапрофітних грибів у грунтових місцеіснуваннях з високим біорізноманіттям. Для подальших досліджень було відібрано два штами: високофітотоксичний A. brassicicola 2855 і A. longipes 16800 (антагоніст $S$. aureus B-909).

Ключові слова: Alternaria, ендофіти, фітопатогени, сапрофіти, біологічно активні метаболіти.

\section{БИОЛОГИЧЕСКАЯ АКТИВНОСТЬ РАЗНЫХ ВИДОВ РОДА ALTERNARIA}

\section{К.С. Цыганенко, Я.И. Савчук, Л.Т. Наконечная, И.Н. Курченко}

Институт микробиологии и вирусологии им. Д.К.Заболотного НАН Украины, ул. Академика Заболотного, 154, Киев, 03143, Украина

\section{Резюме}

Виды рода Alternaria, изолированные из разных экониш, синтезируют широкий круг биологически активных метаболитов. Целью данной статьи была оценка спектра биологической активности мелкоспоровых видов рода Alternaria из разных трофических групп (сапрофиты, эндофиты и фитопатогены) по результатам системного скрининга биологически активных метаболитов в отношении различных тесторганизмов и отбор перспективных штаммов-продуцентов. Методы. Антибиотическую, антифунгальную и фитотоксическую активности культуральных фильтратов и хлороформных экстрактов определяли методом диффузии в агар. Результаты. 19\% культуральных фильтратов из 64 исследованных штаммов проявляли биологическую активность по меньшей мере к одному из тест-организмов. Подавляющее большинство этих грибов принадлежало к эндофитным штаммам и было активным по отношению к фитопатогенным грибам, бактериям и водорослям. Хлороформные экстракты культуральных фильтратов 33\% штаммов проявляли биологическую активность по меньшей мере к одному из тест-организмов. Полученные экстракты имели избирательное специфическое действие по отношению к определенной тесткультуре. Эти препараты ингибировали преимущественно рост Staphylococcus aureus B-909, Chlorella vulgaris 191 и Rizoctonia solani 16036. Выводы. Скрининг 64 штаммов грибов Alternaria, выделенных из различных экологических ниш, позволил сделать вывод о том, что они имеют низкую биологическую активность. Эндофитные штаммы Alternaria характеризовались более широким спектром активностей, чем фитопатогенные и почвенные. Они ингибировали все тест-организмы за исключением грамотрицательных бактерий и дрожжеподобных грибов. Биологически активные метаболиты эндофитных штаммов Alternaria, включая высокомолекулярные соединения, играют важную роль в мутуалистическом сосуществовании эндофитных грибов и растений-хозяев, а также в их распространении. Хлороформные экстракты почвенных сапрофитов имели сравнительно высокую активность особенно против грибов и водорослей. Очевидно, эти низкомолекулярные соединения способствуют адаптивному выживанию сапрофитных грибов в почвенных местообитаниях с высоким биоразнообразием. Для дальнейших исследований были отобраны два штамма: высокофитотоксичный A. brassicicola 2855 и A. longipes 16800 (антагонист S. aureus B-909). 
Ключевые слова: Alternaria, эндофиты, фитопатогены, сапрофиты, биологически активные метаболиты.

1. Lawrence D, Rotondo F, Gannibal Ph. Biodiversity and taxonomy of the pleomorphic genus Alternaria. Mycol Progress. 2016; 15(3):1-22.

2. Meena M, Gupta SK, Swapnil P, Zehra A, Dubey MK, Upadhyay RS. Alternaria toxins: potential virulence factors and genes related to pathogenesis. Front Microbiol. 2017; 8:1451.

3. Lawrence DP, Gannibal PhB, Peever TL, Pryor BM. The sections of Alternaria: formalizing species-group concepts. Mycologia. 2013; 105(3):530-46.

4. Kurup VP, Shen HD, Banergee B. Respiratory fungal allergy. Microb Infect. 2000; 2:1101-10.

5. Peever TL, Su G, Carpenter-Boggs L, Timmer LW. Molecular systematics of citrusassociated Alternaria species. Mycologia. 2004; 96(1):119-34.

6. Pinto VEF, Patriarca A. Alternaria Species and Their Associated Mycotoxins. In: Moretti A, Susca A, editors. Mycotoxigenic Fungi. Methods in Molecular Biology. Vol. 1542. New York: Humana Press; 2017. p. 13-32.

7. Ostry V. Alternaria mycotoxins: an overview of chemical characterization, producers, toxicity, analysis and occurrence in foodstuffs. World Mycotoxin J. 2008; 1:175-88.

8. Frisvad JC, Andersen B, Thrane U. The use of secondary metabolite profiling in chemotaxonomy of filamentous fungi. Mycol Res. 2008; 112:231-40.

9. Andersen B, Thrane U. Differentiation of Alternaria infectoria and Alternaria alternata based on morphology, metabolite profiles, and cultural characteristics. Can J Microbiol. 1996; 42:685-9.

10. Andersen B, Krøger E, Roberts RG. Chemical and morphological segregation of Alternaria alternata, A. gaisen and A. longipes. Mycol Res. 2001; 105:291-9.

11. Andersen B, Krøger E, Roberts RG. Chemical and morphological segregation of Alternaria arborescens, A. infectoria and A. tenuissima species-groups. Mycol Res. 2002; 106:170-82.

12. Andersen B, Dongo A, Pryor BM. Secondary metabolite profiling of Alternaria dauci, A. porri, A. solani, and A. tomatophila. Mycol Res. 2008; 112:241-50.

13. Ntasiou P, Myresiotis C, Konstantinou S, Papadopoulou-Mourkidou E, Karaoglanidis GS. Identification, characterization and mycotoxigenic ability of Alternaria spp. causing core rot of apple fruit in Greece. Int J Food Microbiol. 2015; 197:22-9.

14. Tsuge T, Harimoto Y, Akimitsu K, Ohtani K, Kodama M, Akagi Y, Egusa M, Yamamoto M, Otani H. Host-selective toxins produced by the plant pathogenic fungus Alternaria alternata. FEMS Microbiol Rev. 2013; 37:44-66.

15. Lou J, Fu L, Peng Y, Zhou L. Metabolites from Alternaria fungi and their bioactivities. Molecules. 2013; 18:5891-935.

16. Tsyganenko KS, Zaichenko OM. [Antibiotic properties of some species of genus Aspergillus Mich.]. Mikrobiol Z. 2004; 66(4):56-61. Ukrainian.

17. Savchuk YaI, Zaichenko OM. [Evaluation of potential of micromycetes concerning synthesis of biologically active substances]. Mikrobiol Z. 2010; 72(2):15-21. Ukrainian.

18. Gannibal PhB. Monitoring of alternarioses of crops and identification of fungi of the genus Alternaria. A manual. Levitin MM, editor. St. Petersburg: VIZR; 2011. 
19. Khalid MM, Sudhir Ch. A modified medium for antibiotic production by Aspergillus spp. antagonistic to citrus cancer pathogen. Nat Acad Sci Lett. 1989; 12(4):103-6.

20. Heatley NG. A method for the assay of penicillin. Biochem J. 1944; 38:61-5.

21. Balouiri M, Sadiki M, Ibnsouda SK. Methods for in vitro evaluating antimicrobial activity: A review. J Pharm Anal. 2016; 6(2):71-9.

22. Berto P, Belingheri L, Dehorter B. Production and purification of a novel extracellular lipase from Alternaria brassicicola. Biotechnol Lett. 1997; 19:533-6.

23. Saha D, Fetzner R, Burkhardt B, Podlech J, Metzler M, Dang H, Lawrence C, Fischer R. Identification of a polyketide synthase required for alternariol $(\mathrm{AOH})$ and alternariol-9-methyl ether (AME) formation in Alternaria alternata. PLoS ONE. 2012; 7:e40456.

24. Isshiki A, Akimitsu K, Nishio K, Tsukamoto M, Yamamoto H. Purification and characterization of an endopolygalacturonase from the rough lemon pathotype of Alternaria alternata, the cause of citrus brown spot disease. Physiol Mol Plant Pathol. 1997; 51:155-67.

25. Brakhage AA. Regulation of fungal secondary metabolism. Nat Rev Microbiol. 2013; 11(1):21-32.

26. Kusari S, Hertweck C, Spiteller M. Chemical ecology of endophytic fungi: origins of secondary metabolites. Chem Biol. 2012; 19(7):792-8.

27. Martinez-Klimova E, Rodríguez-Peña K, Sánchez S. Endophytes as sources of antibiotics. Biochem Pharmacol. 2017; 134:1-17.

28. Anyanwu CS, Sorensen JL. Secondary metabolites from a strain of Alternaria tenuissima isolated from Northern Manitoba soil. Nat Prod Commun. 2015; 10(1):3942.

29. Pedras MSC, Chumala PB, Jin W, Islam MS, Hauck DW. The phytopathogenic fungus Alternaria brassicicola: Phytotoxin production and phytoalexin elicitation. Phytochemistry. 2009; 70:394-402.

30. Yang J, Yin Z-Q, Kang Z-T, Liu C-J, Yang J-K, Yao J-H, Luo Y-Y. Transcriptomic profiling of Alternaria longipes invasion in tobacco reveals pathogenesis regulated by AlHK1, a group III histidine kinase. Sci Rep. 2017; 7:16083.

31. Beresteskiy AO. A review of fungal phytotoxins: from basic studies to practical use. Appl Biochem Microbiol. 2008; 44:453-65.

32. Kusari S, Singh S, Jayabaskaran C. Biotechnological potential of plant-associated endophytic fungi: hope versus hype. Trends Biotechnol. 2014; 32(6):297-303.

Отримано 1.04.2018 